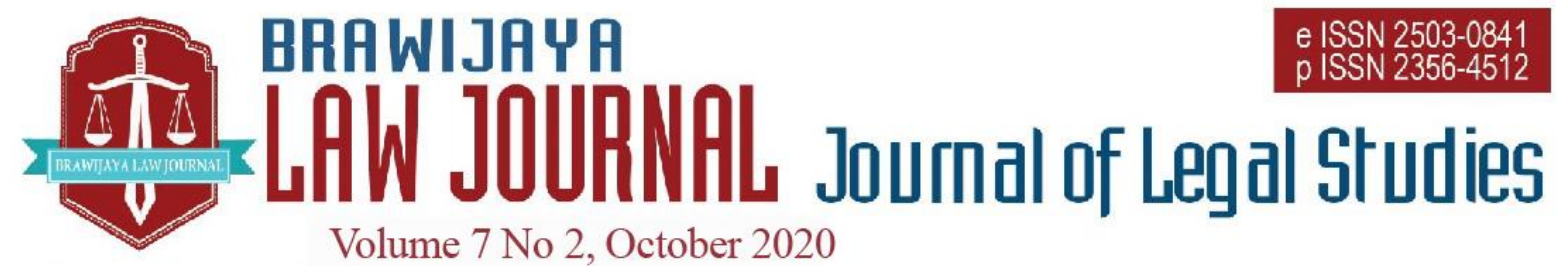

Nationally Accredited No. 30/E/KPT/2018 Dated 24th October 2018

This work is licensed under a Creative Commons Attribution-NonCommercial 4.0 International License

\title{
Law Protection Mechanism of Wage Equality for Women Worker: Indonesian Law and Human Right Perspective
}

\author{
Sukarmi $^{\mathrm{a}}$, Ranitya Ganindha ${ }^{b^{*}}$, Azahlia Umar \\ ${ }^{a}$ Faculty of Law, Universitas Brawijaya, \\ Email: sukarmi@ub.ac.id \\ $\mathrm{b}^{*}$ Faculty of Law, Universitas Brawijaya \\ Email: r.ganindha@ub.ac.id \\ ${ }^{b}$ Faculty of Law, Universitas Brawijaya \\ Email: azahliaumar2012@gmail.com
}

Submitted : 2020-08-28 | Accepted : 2020-09-27

\begin{abstract}
Women labours in Indonesia still experiencing wage discrimination with male labours for works of equal value. Indonesia's efforts to provide protection against discrimination in wage for women labor is by ratifying ILO Convention No. 100 of 1951 and the CEDAW Convention 1979. This journal aims to find out the form of protection of wage discrimination for women labours in Indonesia in accordance with the mandate of the ILO and CEDAW Conventions and the protection mechanism of wage discrimination given by Indonesia to women labours. This journal is a normative study, with a statute approach and a conceptual approach. This journal analyzes that the form of protection of wage discrimination Against women labours in Indonesia is through legislative action through ratification of ILO Convention No. 100 of 1951 with Law No. 80 of 1957 concerning the approval of ILO Conventions No. 100 Regarding Wages for Men and Women for Work of Equal Value, especially those contained in Article 1 letter $(b)$ and Article 2, the ratification of CEDAW through Law No. 7 of 1984 concerning Ratification of the Convention Concerning the Elimination of All Forms of Discrimination Against Women especially those contained in Article 11 Letter (d), Law No. 13 of 2003 concerning Employment specifically regulated generally in Article 5, Article 6, and Article 88 Paragraph (3) Letter (i). The results shows that Indonesia does not yet have regulations that contain special protection mechanisms for wage discrimination provided by Indonesia to women workers in the form of sanctions, reporting mechanisms or special supervision of discriminatory practices, which are not yet regulated either in the Employment Act or the Law ratified by the Convention ILO and CEDAW.
\end{abstract}

Keywords: protection; discrimination; wages; women workers; ilo conventions; cedaw.

\section{INTRODUCTION}

Indonesia is one of the countries that

have ratified the International Labor

Organization (ILO) conventions, which since 
July 12, 1950 have been members of the International Labor Organization. Indonesia became the first country in Asia and was in fifth position in the whole world as a country that had ratified 18 of its conventions. ${ }^{2}$ One important point in the convention is gender equality between women and men workers. ${ }^{3}$

One strategic issue that is widely discussed by developing countries is related to the issue of gender equality. Wage disparities by gender still occur in Indonesia and almost all countries in the world. The patriarchal culture is still visible at the level of practice. ${ }^{4}$ Women have lower achievement than men in various fields. Such conditions are not a good thing in the process of sustainable development. Because, it should be between men and women in an equal position. ${ }^{5}$

Issues related to gender equality are actually not new issues. The increasing level of women's education and awareness of women's empowerment make bargaining positions between men and women to be in an equal position. However, that does not mean there are no problems at all in gender equality, especially in relation to the scope of work. Frequently not realized, an equal position between women and male workers can make the competitiveness of the

1 Preamble of the Republic of Indonesia Law No.80 of 1957 Concerning Approval of the International Labor Organization Conference No. 100 Regarding Equal Remuneration for Men and Women Workers for Work of Equal Value.

2 ILO, 'The ILO in Indonesia' (2014) Jakarta: ILO Publisher

3 ILO Convention No. 100 and ILO Convention No.111

4 Hennigusnia, 'Gender Gap between Gender in Indonesia Glass Ceiling or Sticky Floor?'(2014) Vol.9, Peneliti Pertama Pusat Litbag Ketenagakerjaan Kementrian Ketenagakerjaan RI,(here in after Hennigusnia)

5 Central Bureau of Statistics, Gender Statistics Thematic-Portrait of Gender Inequality in workforce increase. Research conducted by Klasen and Lammana ${ }^{6}$ shows that the reduction in gender disparities in the education area cannot bring significant benefits to economic growth if women's access to productive employment is restricted. In the study also conveyed, existing inequality could reach four times the economic growth. In other words, gender inequality makes economic growth not optimal. $^{7}$

The rights and obligations of women workers in Indonesia are regulated in Law no. 13 of 2003 concerning Employment. Other regulations also contribute to regulating women's worker rights starting from Article 27 paragraph (2) of the 1945 Constitution of the Republic of Indonesia, Law No. 7 of 1984 concerning the Elimination of All Forms of Discrimination against Women, ILO Convention No. 111 concerning AntiDiscrimination in Position and Occupation which has been ratified by Indonesia by Law No. 21 of 1999, and ILO Convention No. 100 concerning Wage Equality which has been ratified by Indonesia with Law No. 80 of 1957.8

Based on the results of the population census of the Central Statistics Agency or BPS in 2018, the total population of women in Indonesia is 131.9 million, while the

Economy, (Jakarta: Publisher: Ministry of PPA, 2016)

6 Stephen Klasen, Francesca Lamanna, 'The Impact of Gender Inequality in Education and Employment on Economic Growth: New Evidence for a Panel of Countries' (2009) 15(3) Feminist Economics, 91-132

7 Central Bureau of Statistics, Thematic Gender Statistics-Portrait of Gender Inequality in Economy, (Jakarta: Publisher: Ministry of PPA, 2016)

8 Annida Addiniaty, 'Weak Legal Protection for Women Workers' (2013) Journal of Rechtvinding Online

164 | Sukarmi, Ganindha, Umar- Law Protection Mechanism of Wage Equality for Women Worker... 
number of men is 134 million, an almost equal number of men and women shows that women's position in the community is just as important as men and also indicates that women are one of the contributors to the progress of the country, particularly in the field of employment. ${ }^{9}$ The ratio of women's wages to men's wages for the same work is only 0.68 or $68 \%$ of men's wages. This value has decreased by comparing it 10 years ago where the ratio was 0.79 or $79 \%$. This shows that Indonesia must catch up with other countries in terms of gender equality in the economic field, which is equality between wages. ${ }^{10}$

All women have rights that are specifically accommodated by law. Women are a group that is considered vulnerable and get special treatment in human rights protection. Basically, women get rights protection in accordance with what is stipulated in the law. The basic principle underlying rights for women is the right of a gender perspective and anti-discrimination which means that women have the same rights and positions as men in various fields such as education, law, work, politics, rights in relation to citizenship, rights in marriage and obligations. ${ }^{11}$

With regard to women workers, the aim of the workers is of course to gain benefit economically through decent remuneration including women workers. Many women workers who work in urban areas with a high level of education or work in the informal sector with a low level of education want to

9 Desia Rakhna Banjari, 'Implementation and Protection of Access to Women's Workers' Rights in Indonesia: Review Law No. 13 of 2003 concerning Employment of the ILO Convention' (2019) 10(1) Jurnal HAM (here in after Banjari)

10 Martesa Husna Laili, Anie Damayanti, 'Intergender Wage Gaps in Indonesia: Empirical Evidence in the Manufacturing Sector' (2018) Indonesian Journal of Economics and Development, p.2 improve the standard of living of the family through good income.

Women who receive unfair treatment at work will bring up the view that women are born to do far more limited work than men with lower employment status. Developing countries have a number of women with lower levels of education so that women are forced to become informal workers with lower wages. In addition, the tendency for women who work in the informal sector is not to get other rights that should be obtained as workers. ${ }^{12}$

The International Labor Organization (2012) states that factors that play a major obstacle to women's ability to transition from the informal labor market to the formal labor market, especially in the non-traditional sector are women's household roles and responsibilities, women's subordinate status in gender relations, and patriarchal attitude towards women's participation in economic and community life. ${ }^{13}$

The development of the labor market in Indonesia in 2014 and 2015 shows that there are problems potentially have threatening human resource development, namely the existence of gender discrimination in labor, where many women work with low wages and more limited career development prospects. This makes the level of participation of women in the workforce still very low when compared to men. ${ }^{14}$ One of the media in Indonesia in 2016 stated that women workers in various regions in Indonesia still experience discrimination in

11 Rhona K. M Smith, et.al. 2008, Human Rights Law, Knut D. Asplund, Suparman Marzuki, Eko Riyadi (Editor), (Yogyakarta: PUSHAM UII), p. 269.

12 Syamsiah Achmad in Dwi Edi Wibowo, Double Role of Women and Gender Equality, accessed from http://ejournal.iainpekalongan.ac.id/index.php/Muwazah/ article/view/6/6 access date June 20, 2020

13 Hennigusnia, above n.4, p. 90

14 Banjari, above n.9 
the workplace. The forms of discrimination is vary, ranging from disparities in work rights to sexual harassment. ${ }^{15}$

Seeing the problems that occur to women workers, the state as an entity that has the obligation to guarantee the implementation of equality and prevent discrimination against women in the world of work is responsible for providing protection for equal pay between women workers and male workers who have the same work and productivity. This protection also provides protection for discrimination against women workers that has occurred as mentioned above.

\section{LEGAL MATERIALS METHODS}

Based on the background above, the legal issues in this journal are:

1. How is the form of Wage Discrimination Protection for Women Workers in Indonesia in accordance with the Mandate of the ILO and CEDAW Conventions?

2. How is the rotection mechanism for wage discrimination that Indonesia provides to Women Workers?

This journal is a normative study, using a statute approach and a conceptual approach. The statute approach is carried out by analyzing various laws and regulations in Indonesia as well as international conventions related to the rights of women workers, especially concerning protection from wage discrimination to understand the philosophical content in it. To support the study to be more comprehensive conceptual approach is also used, namely studying the views, doctrines, concepts and principles of law in order to build a legal argument in solving the issues raised.

\section{RESULT AND DISCUSSION}

Forms of Protection for Wage Discrimination against Women in

Indonesia in Accordance with the Conventions of the ILO and CEDAW Conventions

Wage are the main rights possessed by every worker as a form of reciprocity from the obligations they have performed. ${ }^{16}$ However, so far the wages rising has been based more on pressure from workers, trade unions, or NGOs who have requested wages raise for labours. The relationship between employers and women workers is considered not as a mutually beneficial partner, but women workers are considered as a tools to seek multiple benefits. Because women workers are considered to be more diligent and easy to accept the situation. Employers do not realize that by increasing the role of women workers by considering them as partners in carrying out company activities rather than 'printing machines', it will create more conducive labor relations between workers and employers.

According to the International Labor Organization (ILO) there is still a gap between gender wages in Indonesia with a difference of up to $19 \%$ in 2012 . Women earn an average wage of $81 \%$ of men's wages, despite having the same level of education and experience. ${ }^{17}$
15 Priska Sari Pratiwi, 'Garment Factory Workers Often Experience Sexual Violence', CNNIndonesia, aceessed September 23, 2017, https://www.cnnindonesia.com/national/2016112

\footnotetext{
4152933-20-175048/garment-factory-workersoften-experienced-sexual violence/

16 Article 1 Number (35) of Law No. 13 of 2003 concerning Employment

17 Annida Addiniaty, above n.8
} 
Picture1. Average Worker Wages

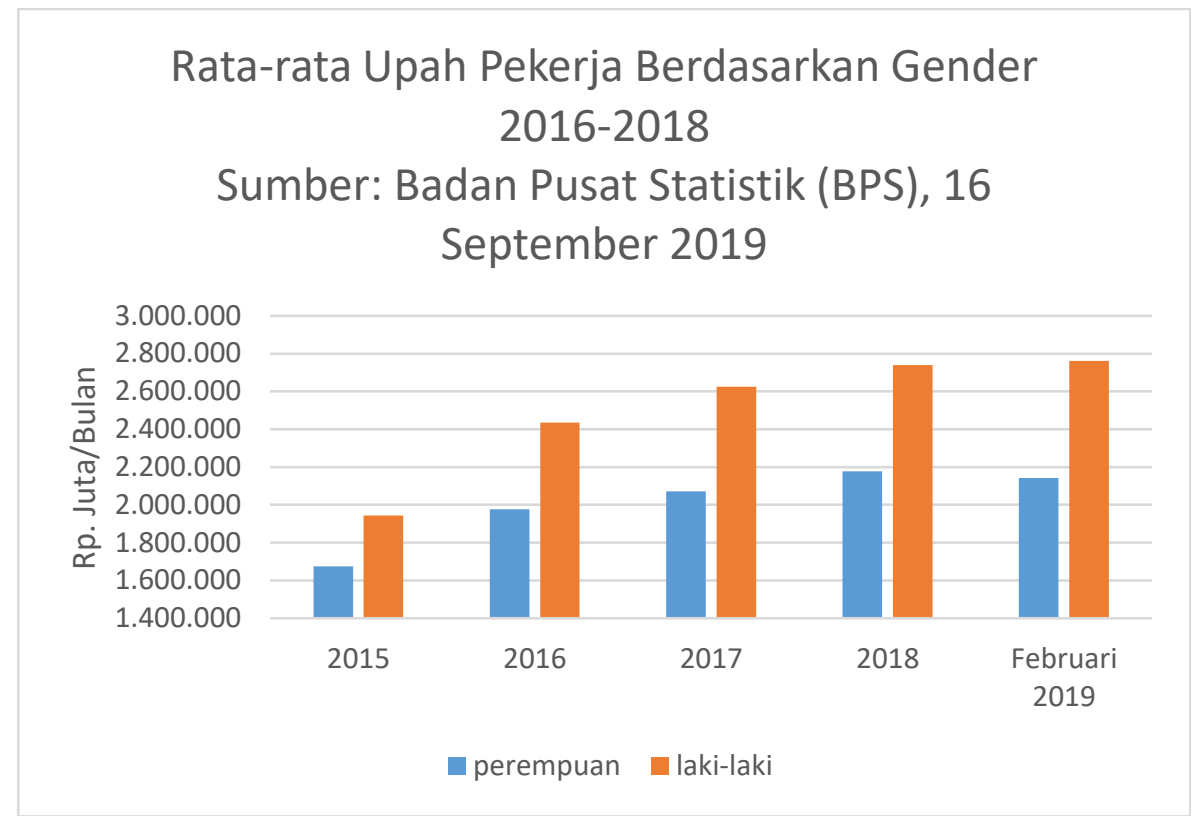

Source: BPS.go.id

Based on data released by the Central Statistics Agency in the 2019 Economic Report there is a widening gap between the wages of women and men workers. The average amount of wages given to male workers is higher than the average wages of women workers. Recorded in the report in the period of 2015-February 2019 the difference between the wages of both of them reached Rp. 492.2 (thousand). More detailed breakdowns related to wage differences are as follows, in 2015 recorded a difference of Rp. 269 thousand, then in 2016 amounted to Rp. 458.4 thousand, the number increased in 2017 Rp. 554 thousand, and an increase in the gap occurred in 2018 Rp. 560, 6 thousand. Whereas in 2019, the gap is widening reach Rp. 618.8 thousand. ${ }^{18}$

BPS report stated that women were given lower wages because they were

18 The Central Bureau of Statistics, 'Indonesia Economic Report 2019', https://www.bps.go.id/publication/download.html ?nrbvfeve=N2NjNjhhZmM0M2FhMGQ4YjllOG VhZjQ3\&xzmn=aHR0cHM6Ly93d3cuYnBzLmd vLmlkL3B1YmxpY2F0aW9uLzIwMTkvMDkv considered not contribute as much as male laborers. Women have reproductive organs so that during menstruation, pregnancy and childbirth they may not be optimal at work. In addition, the position of women as mothers which should take care of their children is considered a weakness of working women. The problem of employment opportunities, wages, and situation or work position is a challenge for women workers in their status as labours. ${ }^{19}$

The level of participation of women workers in the workforce is quite high. Women with productive age dominate the number of women workers. Central Statistics Agency (BPS) Noted that the population of working age in Indonesia as of February 2020 is 199.4 million. This number has increased by 2.92 million workers when compared to February 2019. The Labor Force

MTYvN2NjNjhhZmM0M2FhMGQ4YjllOGVhZj Q3L2xhcG9yYW4tcGVyZWtvbm9taWFuLWluZ G9uZXNpYS0yMDE5Lmh0bWw\%3D\&twoadfn oarfeauf=MjAyMC0xMS0wOSAwODo1Mjo1O Q\%3D\%3D, access date June 16, 2020 at 13.37 19 ibid 
Potential Level (TPAK) surveyed by gender shows that male TPAK is higher than women. In February 2020 the TPAK for women decreased by 94 points to $54.06 \%$ compared to February 2019 which was $55.50 \%$.

The reaserch results showed ${ }^{20}$ that discrimination is a major part of the real wage gap by gender in all wage distribution points, There is wage Gap Between Genders in Indonesia especially at the bottom of the wage distribution. This fact strongly suggests that although Indonesian laws and regulations set equal wages and equal employment opportunities, there was still a lack of appreciation for women's skills in the labor market. So as to achieve gender equality there needs to be strong law enforcement. $^{21}$

In principle, legal protection is the protection provided by the law for human rights to avoid abuse as well as a form of recognition of human rights and dignity. Legal protection covers all efforts given by law enforcers to provide guaranteed racial safety in terms of psychological, physical and various threat and disruption. Legal protection is also interpreted as all legal norms or rules that can protect from interference. $^{22}$

Protection for women workers is formulated through Article 76 paragraphs (1), (2), (3) and (4) Law No. 13 of 2003 concerning Employment, related to the special treatment of women workers with certain working hours, pregnant women workers, and women laborers under the age of 18 . The reason why women workers are

20 Research by Hennigusnia entitled 'Gender Gap Between Gender in Indonesia Glass Ceiling or Sticky Floor?' (2014) Vol.9, First Researcher of the Ministry of Manpower Litbag of Labor

21 Hennigusnia, loc. Cit, p.91

22 Umu Hilmy, 'Pelanggaran dan Perlindungan Hukum Tenaga Kerja di Kabupaten Malang', (2011) 23(3), Mimbar Hukum, p.431 given special protection is because women workers naturally have an important role and function in the life of society, namely the function of reproduction. ${ }^{23}$

Besides Article 76 Law No. 13 of 2003 concerning Employment, other forms of protection provided by that law are through Article 81, Article 82, Article 83, Article 84 and Article 93, Minister of labor Decree No. 224 of 2003 which includes rules of protection related to working hours at night, protection regarding menstruation (women workers can apply for menstrual leave), protection for having maternity leave which time limit is set by law, availability of lactation space in the workplace, recognition of equal work competence with male workers, prohibition of imposing dismissals without reason to women workers, the right to health checks, pregnancy and labor costs.

As a member of the ratification of ILO Conventions, Indonesia has two tasks at once, namely implement application measures that internationally supervised and official commitments to implement convention rules. ${ }^{24}$ There are four main ILO Conventions which prohibit discrimination based on sex and promote gender equality including the Equal Wages Convention 1951 (No.100), Convention of Discrimination (Employment and Occupation), 1958 (No.111), Workers with Family Responsibility Convention, 1981 (No.156) and Convention of Pregnancy Protection, 2000 (No.183). ${ }^{25}$ Following are some ILO standard references to legal norms that affect women workers, as follows: ${ }^{26}$ (a).Equality

23 Maimun, Hukum Ketenagakerjaan Suatu Pengantar, (Jakarta: PT. Pradnya Paramita, 2007), p. 13

24 Banjari, above n.9, p.117

25 ILO, 'The ILO in Indonesia' (Jakarta: ILO Publisher, 2014)

26 Banjari, above n.9 
of wages; (b).Discrimination in employment and position; (c). Protection of pregnancy; (d). Workers with family responsibilities;

ILO Convention No. 100 Concerning Equal Remuneration for Men and Women Workers for Work of the Same Value in 1951 contains arrangements on equal pay for work of the same value where standardized wages are required without discrimination based on gender. In addition, the convention mandates to assess work objectively based on the contents of the work. ${ }^{27}$

Basically Article 28D paragraph (2) Constitution of the Republic of Indonesia which stated: "Everyone has the right to work and to receive compensation as well as fair and proper treatment in employment relations" has called for equal pay for all workers (including women workers) to be treated in a fair which is free from discrimination. Other legal products in Indonesia which regulate equality of wages contained in Article 88 paragraph (1) and (2) Labor Law No. 13 of 2003. Contained in Article 11 of Law No.7 of 1984 concerning Ratification of the Convention Regarding the Elimination of All Forms of Discrimination against Women, There are provisions for sanctions for employers who discriminate wages, as contained in Article 31 PP No. 8 of $1981 .^{28}$

Other legal products in Indonesia which regulate labor wages are contained in Law No. 13 of 2003 concerning employment. Article 5 states that, "Every worker has equal opportunity without discrimination to obtain work." 29 While Article 6 states, "Every worker has the right to receive equal treatment without employer

27 Article 1 (b) dan Article 2 ILO Covention No.100 concerning the Elimination of All Forms of Discrimination Against Women

28 Banjari, above n.9, p.120

29 Article 5 Law Number 13 of 2003 concerning Employment discrimination." 30 Both articles regulate the acquisition and treatment of workers who must be free from discrimination where the meaning is still very broad in relation to what is categorized as 'treatment' whether it is limited to interaction between workers or workers and employers or includes wages as a form of work compensation.

Article 88 paragraph (1) and (2) of Law No. 13 of 2003 concerning Employment states: ${ }^{31}$

1. Every worker / laborer has the right to earn income that fulfill a decent living for humanity.

2. To create income that fulfills a decent living for humanity as referred to in paragraph (1), the government establishes a wage policy that protects workers / laborers.

3. Wage policies that protect workers / laborers as referred to in paragraph (2) include:
a. minimum wage;
$b$. overtime wages;
c. wages for those who do not come to work due to absent;
d. Wage for those who do not come to work due to other activities outside of work;
e. Wage for exercising his right to time off work;
f. Wages form and payment method
g. fines and deductions of wages;
$h$. things that can be calculated with wages;
i. proportional wage structure and scale;
j. Wage for severance pay; and
$k$. Wage for income tax calculation.

30 Article 6 Law Number 13 of 2003 concerning Employment

31 Article 18 Law Number 13 of 2003 concerning Employment 
Based on the contents of the article above, workers (regardless of whether they are man or women) are entitled to a decent income for humanity guaranteed by the government's wage policy. The remuneration category that is protected by government policy as mentioned in Article 88 Paragraph (3) generally states that anti-discrimination wage protection measures for women workers who have the same work and productivity as one of the wage protection categories in government policies, namely those contained in letter (i) which states 'proportional wages' as a reference in structuring and scaling out wages for workers. Proportional 32 itself implies balanced, comparable, and in accordance with the proportions, in this case the proportion of wages received by laborers with the work that have been done, and the balance between wages received between workers where the work is have the same value.

Although the legal protection regulation in the Law No. 13 of 2003 concerning Employment have not answered all issues that are so broad and complex, but at least it is one step ahead and is expected to provide legal protection to workers, especially those concerning work requirements, working conditions and social guarantees and other work protection that can be used as a reference in the settlement of industrial relations disputes. The implementation of legal protection, maintenance and improvement of welfare is the responsibility and obligation of the state. The benefits of legal protection can provide workers with a sense of security so that they

32 Kamus Besar Bahasa Indonesia

33 Banjari, above n.9, p.121

34 Article 11 (1) (d) Law No. 7 of 1984 concerning Ratification of the Convention Concerning the can concentrate more on increasing motivation and work productivity.

The Ratification of Convention on the Elimination of All Forms of Discrimination Against Women (hereinafter referred to as CEDAW) by Indonesia through Law No.7 of 1984 concerning Ratification of the Convention Regarding the Elimination of All Forms of Discrimination Against Women is one form of efforts to protect women workers from discrimination. ${ }^{33}$ Article 11 Law No.7 of 1984 concerning Ratification of the Convention Concerning the Elimination of All Forms of Discrimination against Women states:

"State parties must take all appropriate measures to eliminate women's discrimination in the field of work to ensure, based on equality of men and women, equal rights, in particular: (d) The right to the same wages, including benefits, and to equal treatment in terms of work of equal value, and equality of treatment in evaluating quality of work. ${ }^{34}$

Based on Article 11 above it is stated that state parties have an obligation to regulate the elimination of discrimination against women in employment to obtain the same basic rights as men. In particular, the right to have a job as a human right, the right to equal employment opportunities, the right to choose a profession or work freely, the right to receive equal pay including all benefits, both for equal recognition of the value of work, or an assessment on the quality of work, the right to social security and the right to protection and work safety.

The CEDAW Convention has provided women workers with a clear form of

\footnotetext{
Elimination of All Forms of Discrimination Against Women
} 
protection against all forms of discrimination in the work world, especially those concerning the right to equal wages, where there should be no discrimination or disparity between the wages of women workers and men in terms of work of equal value which in line with the mandate of ILO Convention No. 100 of 1951 and mandated by Law No. 13 of 2003 concerning employment.

\section{Protection Mechanism for Wage Discrimination provided by Indonesia to Women Workers}

Wages play a very important role and a characteristic of an employment relationship. In fact, wages are the main goal of a worker who does work for another person or legal entity. That is become the reason for the government to participates in handling this wage problem through various policies as outlined in the Laws and Regulations. ${ }^{35}$ For workers, wages are something that must be fought for. Wages are the main reason that workers commit themselves to their employers.

Wages are the right of every workers. For this reason, the Government regulates various regulations that provide protection related to wages in Indonesia. A decent minimum wage is an embodiment of a decent income and in accordance with the rights of workers. Determination of the amount of wages is determined based on the calculation of the cost of living in an area. ${ }^{36}$ According to Article 1 number 30 of Law Number 13 of 2003 concerning Employment, wages are the right for workers or laborers received and expressed in the form of money in return

35 Suhartoyo, 'Perlindungan Hukum Bagi Buruh Dalam Sistem Hukum Ketenagakerjaan Nasional' (2019) 2(2), Adminitrative Law \& Governance Journal, p.4

36 B. Siswanto Sastrohadiwiryo, Manajemen Tenaga Kerja Indonesia Pendekatan Administrasi dan Operasional, Cet. 2, p.15 from employers or employers for workers or laborers who are determined and paid according to the agreement work, agreements, or statutory regulations, including benefits for workers or laborers and their families for work and or services that have been or will be done. ${ }^{37}$

Citing the opinion of the Indonesian Minister of Finance, Sri Mulyani, inequality in the rights of women and men workers still occurs in Indonesia. Inequality does not only occur at the level of participation, but also on the amount of wage received. Women receive awage of $32 \%$ adrift compared to men. The imbalance occurs because of the stereotypes received by women which the contribution made by women to their work is not as big as men. In terms of social norms, women are considered only complementary. Even Though in fact, a number of studies show that women have a very significant role in the world of work.. ${ }^{38}$

At the normative level, the government's effort to present a mechanism of protection to workers from gaps that occur between workforces is through Government Regulation No. 5 of 1989 which regulates the imposition of sanctions on companies that violate the minimum wage provisions. Sanctions stipulated in the regulation are deemed unable to provide adequate protection, because sanctions are relatively light ie only a fine of Rp. 100.000, - and sanctions imprisonment for three months. The provision of light sanctions makes the regulation less effective in its implementation. Employers seem to ignore because of the light sanctions.

37 Suhartoyo, above n. 35, p.7

38 'Sri Mulyani: Upah Pekerja Wanita masih Di Bawah Pria sebesar 32\%'. https://economy.okezone.com/read/2019/03/13/32 0/2029492/sri-mulyani-upah-pekerja-wanitamasih-32-lebih-rendah-dari-pria, accessed 29 June 2020 
The above Government Regulation is an effort to enforce the law on the provisions of the UMK as stipulated in Law No. 13 of 2003 concerning Employment, as an effort to guarantee legal certainty. The provision of fines and criminal sanctions against employers who violate the provisions of the UMK is one form of real legal protection mechanism for workers in Indonesia, although there are problems themselves related to the low sanctions provided that enable employers who violate not get a deterrent effect from the sanctions.

The ILO as one of the International Labor Organizations which ratified some of them by Indonesia issued a Resolution Concerning he Promotion of Gender Equality, Pay Equity and Maternity Protection in 2004. The resolution contains a call for all countries in the world to contribute to eliminating all forms of discrimination in the labor market and promoting gender equality especially in the field of work, one of which is through the making of national regulations which prioritize, one of which is, equal pay for women workers with work of equal value, as regulated in Article 1 which emphasizes:

1. Calls upon all governments and social partners to actively contribute - in their respective fields of competence: (i) develop and implement national policies to provide equal opportunities and access for women and men to education, training, career development and employment, as well as equal pay for work of equal value ${ }^{39}$;

Furthermore, ILO member countries are recommended to strengthen legislation relating to anti-discrimination guarantees for

39 Article 1 (i) ILO Resolution Concerning The Promotion of Gender Equality, Pay Equity and Maternity Protection 2004 women workers regulated in Article 2 which reads: "introduce or strengthen appropriate legislation, programmes and other measures aimed at eliminating gender discrimination in the workplace." 40 This means that the government should provide protection mechanisms not only to the extent outlined in legal products or laws, but also in the form of programs or special measures that aims to eliminate gender discrimination in the workplace. This special program or step can be in the form of certain reporting methods for women workers who experience discrimination, supervisory institutions of gender discrimination in the workplace, sanctions for employers who discriminate wages for women workers, or other steps that can make effective protection of women workers from wage discrimination in his work environment as guaranteed in the Act.

In general, Indonesian Legislation related to labor has provided protection for women workers related to protection to receive non-discriminatory treatment, recognition of competence in the world of work, rights related to the reproductive system such as menstrual leave, maternity leave and protection related to working hours at night. Specifically, regarding wages, the law stipulates that women and male workers must be given the same salary calculation without discrimination. However, at the implementation level not all of the rules are easy to enforce. The provision of antidiscriminatory guidelines is not followed by other protection mechanisms, either in the form of financial penalties, prison sanctions or programs or other reporting mechanisms that can be taken by women workers who feel they are experiencing wage discrimination,

40 Article 2 (b) ILO Resolution Concerning The Promotion of Gender Equality, Pay Equity and Maternity Protection 2004 
so employers easily ignore these rules which results in regulations that are not work effectivelly.

Although it has been guaranteed in various laws and regulations and international conventions, but until now not all the rights of women workers can be fulfilled, both caused by internal factors and external factors. The internal factor is the low level of knowledge and understanding of women workers regarding their rights. There are also external factors, namely: (1) the existence of a patriarchal culture; (2) marginalization at work; (3) the existence of stereotypes to women; and (4) ${ }^{41}$ lack of socialization. In addition, the essence of the prohibition of discrimination is also not followed by sanctions for employers who violate the anti-discrimination rules which also a factor is causing violations of the rights of women workers.

\section{CONCLUSION AND SUGGESTION}

From the overall explanation and analysis presented above, this journal produces several conclusions.

1. Indonesia has made efforts to protect women workers from wage discrimination on work of equal value through legislative action in the form of ratification of ILO Convention No. 100 of 1951 with Law No. 80 of 1957 concerning the approval of ILO Conventions No. 100 Regarding Wages for Men and Women for Work of Equal Value, especially those contained in Article 1 letter (b) and Article 2, the ratification of CEDAW through Law No. 7 of 1984 concerning Ratification of the Convention Concerning the Elimination of All Forms of Discrimination Against Women especially those contained in
Article 11 Letter (d), Law No. 13 of 2003 concerning Employment specifically regulated generally in Article 5, Article 6, and Article 88 Paragraph (3) Letter (i).

2. Indonesia does not yet have regulations that contain special protection mechanisms for wage discrimination provided by Indonesia to women workers in the form of sanctions, reporting mechanisms or special supervision of discriminatory practices that do not yet exist either regulated in the Employment Act or the ratification Law of the ILO and CEDAW Conventions.

From all of the explanations and conclusions described above, this journal provides several suggestions.

1. The Indonesian government can optimize the protection of wage discrimination against women workers by establishing special protection mechanisms either through fines (which are sufficient in number and can provide a deterrent effect) or criminal sanctions for employers who violate the anti-wage discrimination provisions against women workers

2. The Indonesian government can create a special supervisory body or agency that is tasked with supervising and guaranteeing the protection of women workers, especially protection from discrimination in the world of work.

3. A special reporting mechanism should be made for women workers who feel discriminated in their workplace, in particular discrimination against wages for work of equal value. There must be guarantees and security for women

41 Ibid 
workers who do the reporting not to be dismissed from their workplaces.

\section{REFERENCES}

\section{Books}

Sastrohadiwiryo, B. Siswanto, Manajemen Tenaga Kerja Indonesia Pendekatan Administrasi dan Operasional, Cet. 2. Maimun, Hukum Ketenagakerjaan Suatu Pengantar, (Jakarta: PT. Pradnya Paramita, 2007)

\section{Journal Articles}

Addiniaty, Annida, 'Lemahnya Perlindungan Hukum Bagi Buruh Wanita' (2013) Jurnal Rechtvinding Online

Achmad, Syamsiah in Dwi Edi Wibowo, 'Peran Ganda Perempuan dan Kesetaraan Gender' (Double Role of Women and Gender Equality), accessed from http://ejournal.iainpekalongan.ac.id/index.ph p/Muwazah/article/view/6/6 access date June 20, 2020

Banjari, Desia Rakhna, 'Pelaksanaan dan Perlindungan Akses Hak Pekerja Wanita di Indonesia: Telaah UU No 13 Tahun 2003 Tentang Ketenagakerjaan atas Konvensi ILO' (Implementation and Protection of Access to Women's Workers' Rights in Indonesia: Review Law No. 13 of 2003 concerning Employment of the ILO Convention) (2019) 10(1) Jurnal HAM

Hennigusnia, 'Kesenjangan Upah Antar Gender di Indonesia Glass Ceiling atau Sticky Floor?' (Gender Gap between Gender in Indonesia Glass Ceiling or Sticky Floor?) (2014) 9, Peneliti Pertama Pusat Litbag Ketenagakerjaan Kementrian
Hilmy, Umu, 'Pelanggaran dan Perlindungan Hukum Tenaga Kerja di Kabupaten Malang', (2011) 23(3), Mimbar Hukum, p.431

Klasen, Stephen, Francesca Lamanna, 'The Impact of Gender Inequality in Education and Employment on Economic Growth: New Evidence for a Panel of Countries' (2009) 15(3) Feminist Economics, 91-132

Martesa Husna Laili, Anie Damayanti, 'Kesenjangan Upah Antargender di Indonesia: Bukti Empiris di Sektor Manufaktur' 'Intergender Wage Gaps in Indonesia: Empirical Evidence in the Manufacturing Sector' (2018) Jurnal Ekonomi dan Pembangunan Indonesia

Pratiwi, Priska Sari, 'Garment Factory Workers Often Experience Sexual Violence', CNNIndonesia, aceessed September 23, 2017, https://www.cnnindonesia.com/nation al/20161124152933-20-

175048/garment-factory-workersoften-experienced-sexual violence/

Smith, Rhona K. M, et.al. 2008, Human Rights Law, Knut D. Asplund, Suparman Marzuki, Eko Riyadi (Editor), (Yogyakarta: PUSHAM UII) Suhartoyo, 'Perlindungan Hukum Bagi Buruh Dalam Sistem Hukum Ketenagakerjaan Nasional' (2019) 2(2), Adminitrative Law \& Governance Journal

\section{Reports}

Badan Pusat Statistik, Statistik Gender Tematik-Potret Ketimpangan Gender dalam Ekonomi, (Jakarta: Penerbit: Kementerian PPA, 2016)

Badan Pusat Statistik, Laporan Perekonomian Indonesia 2019 


\section{Online Sources}

'Sri Mulyani: Upah Pekerja Wanita masih Di

Bawah Pria sebesar 32\%?. https://economy.okezone.com/read/20 19/03/13/320/2029492/sri-mulyaniupah-pekerja-wanita-masih-32-lebihrendah-dari-pria, accessed 29 June 2020

\section{Laws and Regulations}

ILO Resolution Concerning the Promotion of Gender Equality, Pay Equity and Maternity Protection 2004

Kamus Besar Bahasa Indonesia

ILO Convention No. 100 of 1951 with Law No. 80 of 1957 concerning the approval of ILO Conventions No. 100 Regarding Wages for Men and Women for Work of Equal Value

Law No.13 Year 2003 on Employment 